\title{
Bruce King, From New National to World Literature: Essays and Reviews
}

\section{Emma Bird}

\section{(2) OpenEdition}

1 Journals

Electronic version

URL: https://journals.openedition.org/ces/4556

DOI: $10.4000 /$ ces.4556

ISSN: 2534-6695

Publisher

SEPC (Société d'études des pays du Commonwealth)

\section{Printed version}

Date of publication: 1 September 2017

Number of pages: 163-164

ISSN: 2270-0633

\section{Electronic reference}

Emma Bird, "Bruce King, From New National to World Literature: Essays and Reviews", Commonwealth Essays and Studies [Online], 40.1 | 2017, Online since 02 April 2021, connection on 27 January 2022 URL: http://journals.openedition.org/ces/4556 ; DOI: https://doi.org/10.4000/ces.4556

This text was automatically generated on 27 January 2022.

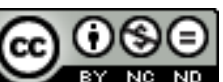

Commonwealth Essays and Studies is licensed under a Licence Creative Commons Attribution - Pas d'Utilisation Commerciale - Pas de Modification 4.0 International. 


\title{
Bruce King, From New National to World Literature: Essays and Reviews
}

\author{
Emma Bird
}

\section{REFERENCES}

Bruce King. From New National to World Literature: Essays and Reviews. Stuttgart: ibidemVerlag, 2016. 632 p. ISBN (hb): $9783838208565 . € 98$

1 From New National to World Literatures brings together a selection of Bruce King's literary reviews and essays, published in various leading Commonwealth, postcolonial and world literary journals and collected volumes over more than four decades. King has written widely on writers and texts from across the world, and has particular interests in West African novels and poetry, Caribbean literature, white settler writing, modern Indian poetry, Black British literature, and Pakistani fiction. The pieces reflect his wide-ranging expertise, and include essays on prominent and lesser-known figures. King has always been a critical and at times antagonistic presence in postcolonial studies, moreover, challenging what he refers to in one essay as its "generalizations and polarities" and its reliance on a "simplified version of dialectics and its polarized contrasts between black and white, dominant and dominated, alien and native" (355). Alongside reviews of individual writers and texts then, there are also insightful reflections on broader topics such as national literature, nationalism, ethnic identity, alienation, modernism, and globalization.

2 Despite the range of subject matter, the volume has a common objective: it "can be read as a story about how a major area of literary study has developed" - not only in response to political and cultural transformations, but also as a consequence of King's own encounters with texts: it is "bound to be personal, even autobiographical, influenced by where I taught and what interested me [...] along with what was happening in the literary and cultural world" (3). One of the most fascinating pieces is a personal account of Derry Jeffares - a name that may not be familiar today, but who 
was instrumental in forging a space for Commonwealth literary studies in the 1960 s. Jeffares was one of the earliest critics to recognize the exciting and innovative creative literatures emerging from the former colonies, and found ways to offer practical forms of support to new writers: among other things, he founded the International Association for the Study of Irish Literature, co-founded the journal ARIEL, and organized the first Commonwealth Literature Festival in Leeds in 1964. As Head of English at Leeds University, Jeffares also transformed the department into a vibrant community of writers from Britain and the Commonwealth, and used his connections to help young academics like King secure jobs at universities abroad. As King suggests, it is not only academics of his own generation who owe a special debt to Jeffares; he has shaped the entire field of postcolonial criticism, and his role deserves to be more widely recognized.

Whether he is writing on West African poetry or Caribbean fiction, Jewish novelists or Indian poets, King is committed to charting the relationship between literature - its form, style, subject matter - and the transformations occurring in the political, material and social sphere. He is especially attentive to the ways in which changes to higher education in the Commonwealth helped create the conditions for new writing styles to develop: in a piece on Nigerian literature, King describes how and why the University of Ibadan emerged as a centre for writers like Christopher Okigbo, Wole Soyinka, J.P. Clark and Chinua Achebe, noting parallels between this creative community and others at new universities in the Caribbean and India too (41). These universities not only brought writers into contact with one another's work, but also gave them "an audience, readership, critics and publicity" (41). As he observes in another essay, the "vigorous local literatures" that flourished in the period following decolonization were able to do so because of emergent cultural infrastructures, including the founding of new universities, the establishment of publishing houses, and the creation of academic journals and little magazines (171).

Although King writes extensively on individual writers and specific texts, he always places them in a wider historical context, probing the relationships between national literatures. Indeed, King's insistence that critics attend to the interconnectivity of literature pre-empts much recent critical work by theorists such as Jahan Ramazani or Neil Lazarus, both of whom have identified resonances between modern texts from across the world. In a piece published in 1983, King noted that "the post-colonial world is remarkable for its internationalism" (157); it should therefore come as no surprise to find writers from different parts of the world - or from different periods in time invoking a shared aesthetic or political tone. In one remarkable essay on Indian poetry, King details the increasingly close relationship between modern American and Indian writers from the 1950s and 1960s onwards, noting the emergence of a shared style and set of interests.

5 Perhaps inevitably, given King's own career, certain figures feature more prominently than others; he writes extensively about Nigerian writers, for example, and includes five reviews or essays on Derek Walcott. However, each piece offers a new and distinctive perspective on Walcott's work: his article on the relationship between West Indian drama and the Rockefeller Foundation, for instance, reflects on Walcott's involvement with the organization, and how it helped develop his career; another article provides an account of the education system in the West Indies, considering how 
Methodism contributed to its arts and cultural scene; and the most recent piece on Walcott gives a detailed account of his volume White Egrets.

6 As King notes in his introduction, his career has charted his discovery of "a seemingly ever expanding literary universe" (14). Alongside articles on Walcott, Soyinka, Achebe and other prominent names, therefore, he includes pieces on various other writers whose work he has encountered and enjoyed, and who he feels deserve to be more widely read - among them Abioseh Nicol, Gabriel Okara, Mordecai Richler, Frank Moorhouse, Keki Daruwalla and Alamgir Hashmi. Hence, although this volume undoubtedly contributes to postcolonial and world literary studies, and has much to offer scholars working on some of its more prominent figures, this is above all a collection of essays for readers who share King's capacious interest in texts, writers and the world. His primary commitment, he notes, is to literature, and his motivation to continue writing comes from his belief that his readers share his love of texts: "It remains possible to be a literary critic and still imagine that you are writing for readers who enjoy literature" (14).

\section{AUTHORS}

\section{EMMA BIRD}

Emma BIRD is a British Academy Postdoctoral Research Fellow at the University of Warwick. Her project examines the material contexts of poetry publishing in postcolonial Bombay / Mumbai, focusing on the city's networks of little magazines and small presses. She has articles published or forthcoming in the Journal of Postcolonial Writing, Wasafiri, the Journal of Commonwealth Literature, and Postcolonial Text. 